\title{
Correction to: USP13 functions as a tumor suppressor by blocking the NF-kB-mediated PTEN downregulation in human bladder cancer
}

\author{
Xiaojun Man ${ }^{1}$, Chiyuan Piao ${ }^{1}$, Xuyong Lin² ${ }^{2}$ Chuize Kong ${ }^{1}$, Xiaolu Cui ${ }^{1 *}$ and Yuanjun Jiang ${ }^{1 *}$
}

\section{Correction to: J Exp Clin Cancer Res 38, 259 (2019) https://doi.org/10.1186/s13046-019-1262-4}

Following publication of the original article [1], the authors identified minor errors in Figs. 2, 4 and 6, specifically:

- In Fig. 2e, incorrect image was used for migration of 5637 cells after miR-301b overexpression $\left(1^{\text {st }}\right.$ row, $3^{\text {rd }}$ column)

- In Fig. 2h, incorrect images were used for UM-UC-3/ Sh-USP13 ( $2^{\text {nd }}$ row, $1^{\text {st }}$ and $2^{\text {nd }}$ columns $)$

- In Fig. 4f, incorrect image was used for migration assay of UM-UC-3 ( $4^{\text {th }}$ row, $2^{\text {nd }}$ column)

- In Fig. 6a, incorrect images were used to demonstrate USP13 Low for both PTEN and USP13 immunohistochemistry staining $\left(2^{\text {nd }}\right.$ row, $1^{\text {st }}$ and $2^{\text {nd }}$ columns)

The corrected figures are given here. The corrections do not have any effect on the final conclusions of the paper. The original article has been corrected.
Published online: 09 December 2021

\section{Reference}

1. Man X, Piao C, Lin X, et al. USP13 functions as a tumor suppressor by blocking the NF-kB-mediated PTEN downregulation in human bladder cancer. J Exp Clin Cancer Res. 2019;38:259. https://doi.org/10.1186/ s13046-019-1262-4.

\section{Author details}

'Department of Urology, First hospital of China Medical University, No.155

Nanjing north Road, Shenyang 110001 , Liaoning, China. ${ }^{2}$ Department of Pathology, The First Affiliated Hospital and College of Basic Medical Sciences, China Medical University, Shenyang 110001, China.

The original article can be found online at https://doi.org/10.1186/s13046019-1262-4.

*Correspondence: cui_ruby@hotmail.com; 13804064945@163.com

${ }^{1}$ Department of Urology, First hospital of China Medical University,

No.155 Nanjing north Road, Shenyang 110001, Liaoning, China

Full list of author information is available at the end of the article permits use, sharing, adaptation, distribution and reproduction in any medium or format, as long as you give appropriate credit to the original author(s) and the source, provide a link to the Creative Commons licence, and indicate if changes were made. The images or other third party material in this article are included in the article's Creative Commons licence, unless indicated otherwise in a credit line to the material. If material is not included in the article's Creative Commons licence and your intended use is not permitted by statutory regulation or exceeds the permitted use, you will need to obtain permission directly from the copyright holder. To view a copy of this licence, visit http://creativecommons.org/licenses/by/4.0/. The Creative Commons Public Domain Dedication waiver (http://creativeco mmons.org/publicdomain/zero/1.0/) applies to the data made available in this article, unless otherwise stated in a credit line to the data. 


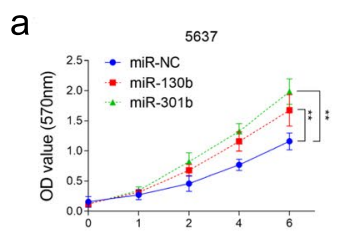

Days

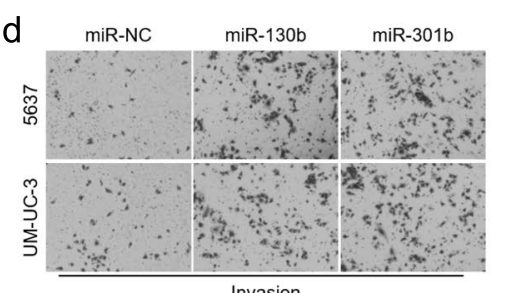

e

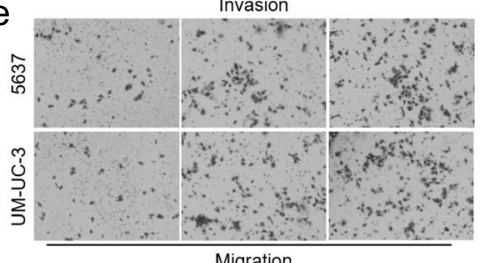

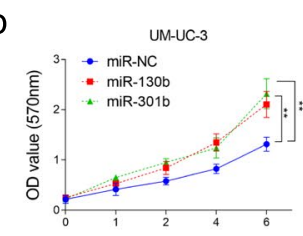

Days
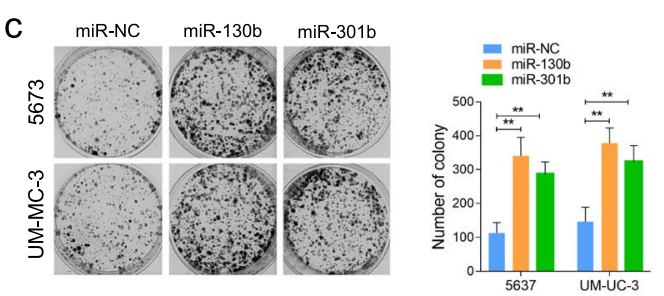
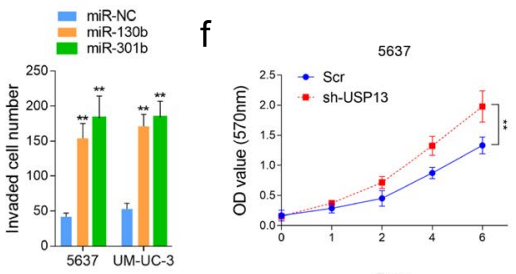

Days

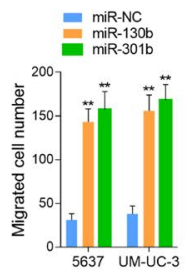

g

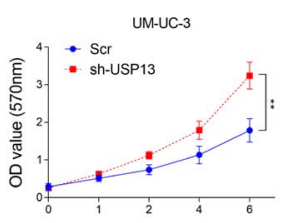

Days
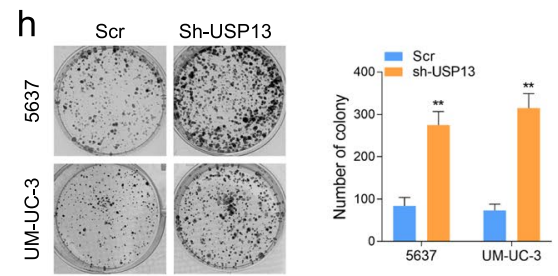
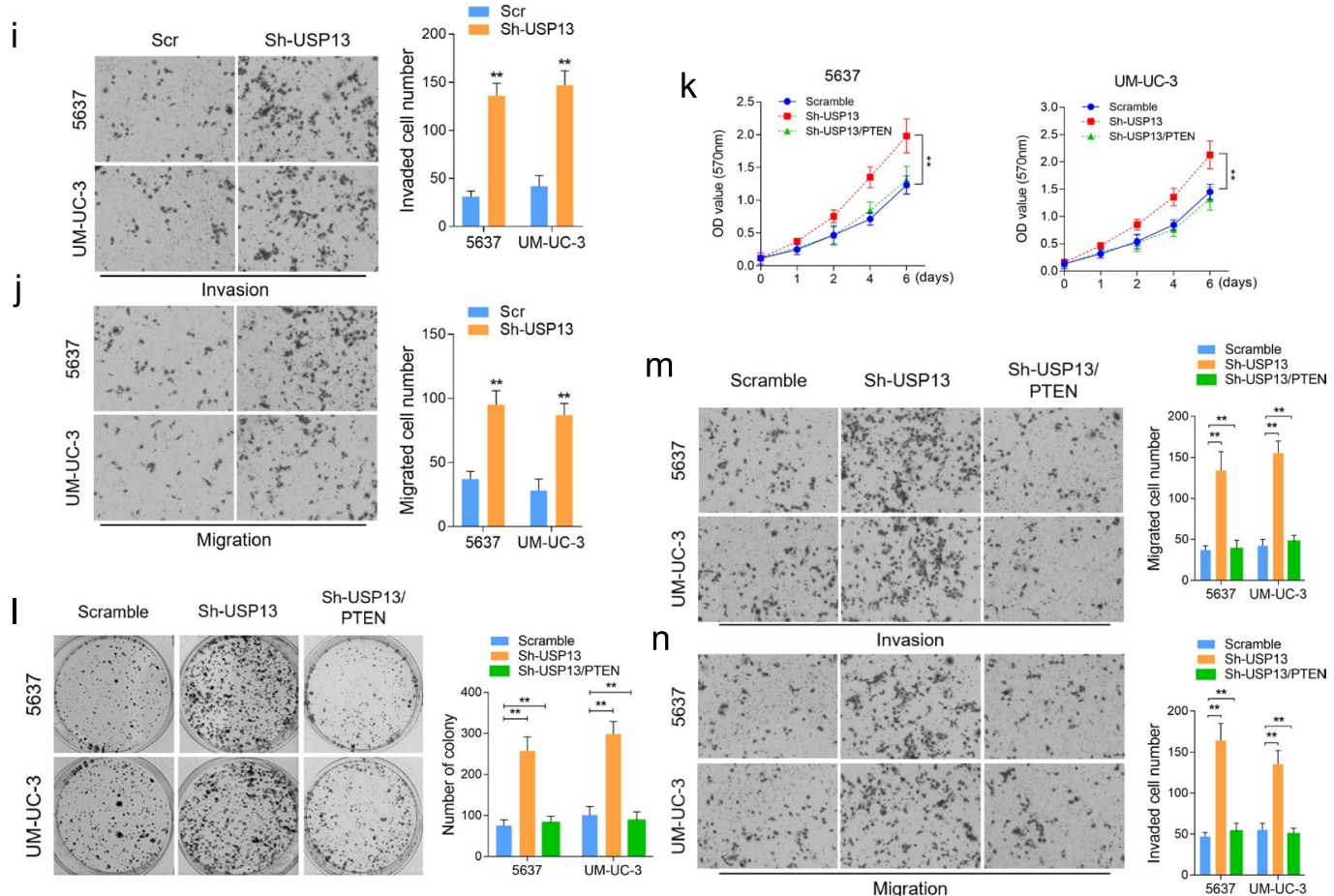

Fig. 2 The biological function of miR-130b/301 b and USP13 in vitro. Cell proliferative capacity was measured by Cell Counting-Kit 8 (CCK-8) (a and b) assay and colony formation assay (e) in miR-130b/301 b overexpressed 5637 and UM-UC-3 cells. CCK-8 (c and d) and colony formation assay (f) were also performed to evaluate the cellular proliferation in USP13 knocked down 5637 and UM-UC-3 cells. Cell invasive and migrative capacities were measured by transwell assay in miR-130b/301 b overexpressed ( $\mathbf{g}$ and $\mathbf{h}$ ) or USP13 knocked down (i and j) 5637 and UM-UC-3 cells. Cell proliferation was detected by CCK-8 (k) and colony formation assay (I) in USP13 knocked down alone or USP13 knocked down as well as PTEN expression restored 5637 and UM-UC-3 cells. Cell invasive $(\mathbf{m})$ and migrative (n) capacities were measured by Transwell assay in USP13 knocked down alone or USP13 knocked down as well as PTEN expression restored 5637 and UM-UC-3 cells. Original magnification: $400 \times{ }^{*} P<0.05$ and ${ }^{* *} P<$ 0.01 , as determined by Student's T-test 


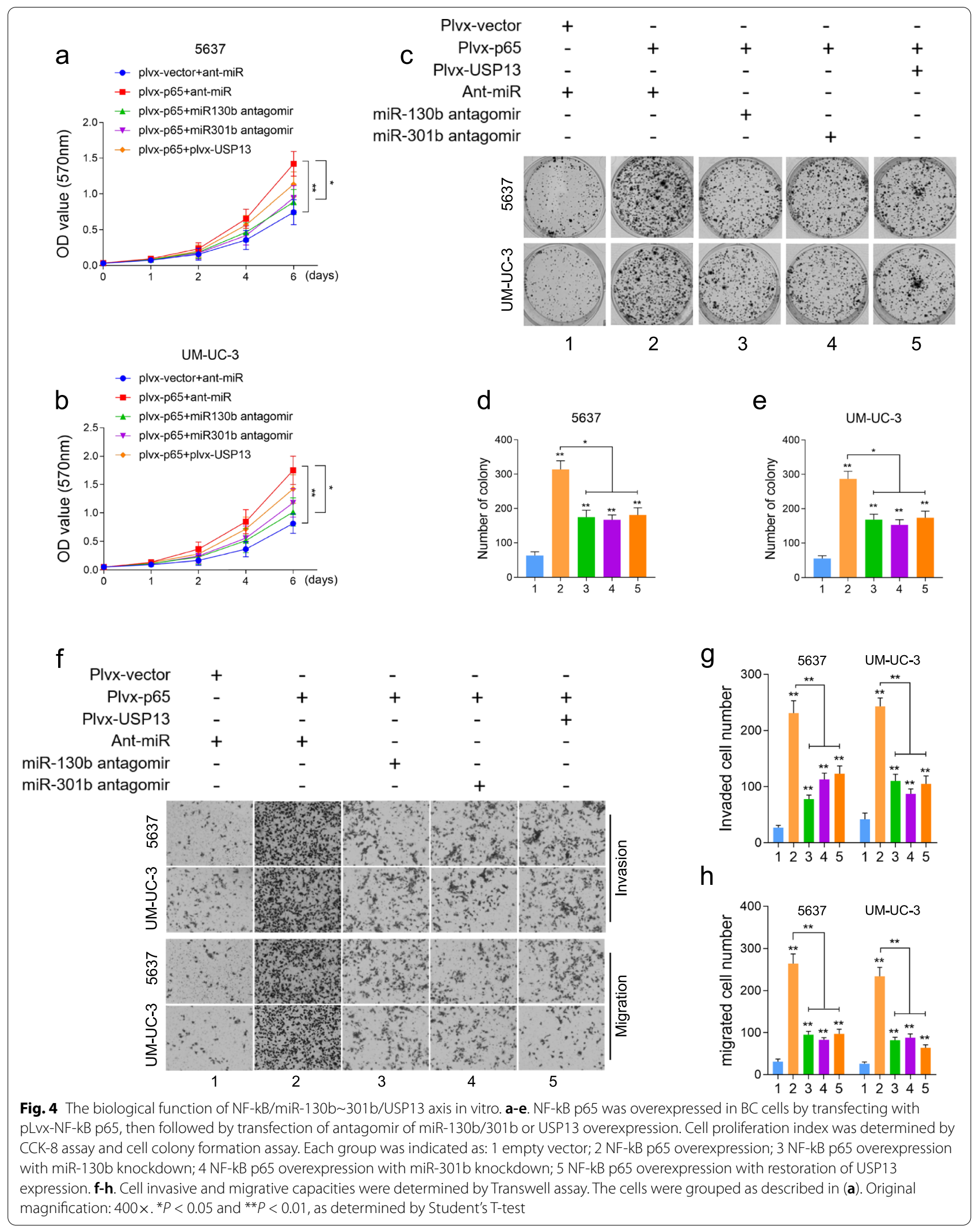




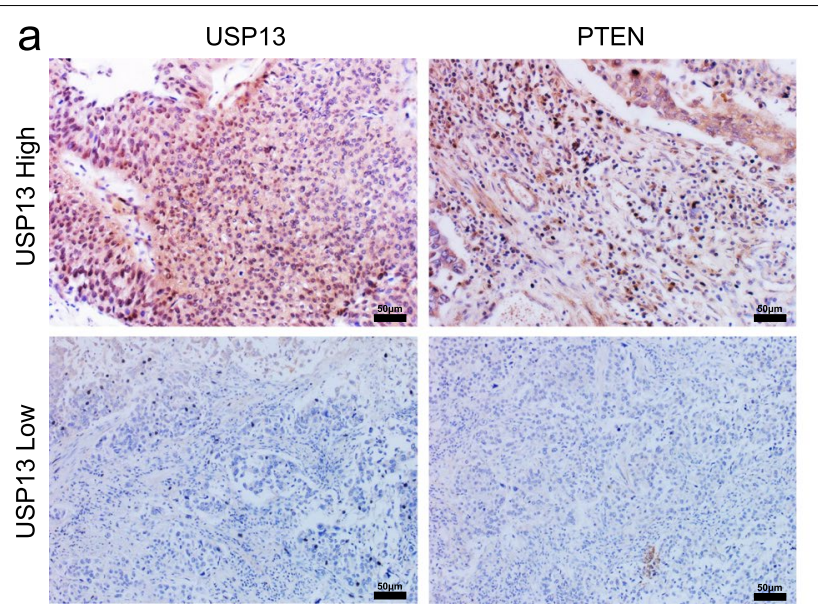

b

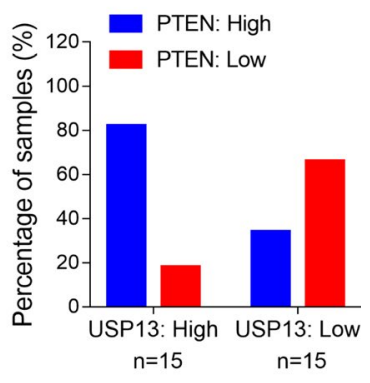

Fig. 6 High PTEN levels correlate with USP13 overexpression in a subset of human bladder cancer tissue specimens. a. Representative images demonstrating PTEN and USP13 immunohistochemistry (IHC) staining of human bladder cancer tissue specimens from 30 bladder cancer patients. b. Quantification of PTEN or USP13 staining in BC tissue specimens. Staining intensity of PTEN or USP13 was scored as 0 to3 (0: no staining, 1: weak staining, 2: medium staining, and 3: strong staining. 0 and 1 were classified as low-expression, whereas 2 and 3 were defined as high-expression. High PTEN expression was correlated with high USP13 expression $(P<0.05$, Fisher's exact test) 